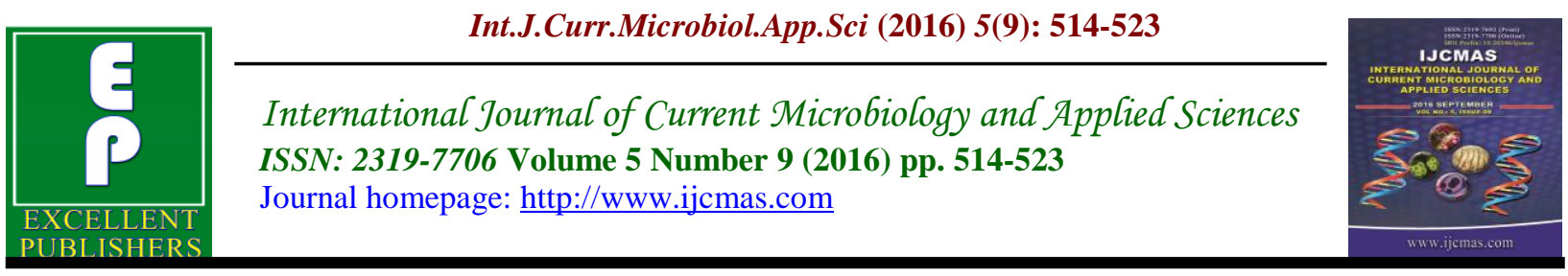

Original Research Article

http://dx.doi.org/10.20546/ijcmas.2016.509.057

\title{
Haemagglutination and Resistance to the Bactericidal Activity of Serum as the Urovirulence Markers of Uropathogenic Escherichia coli
}

\author{
S.M. Nachammai ${ }^{1 *}$, Karthika Jayakumar ${ }^{2}$, Vinithra Suresh ${ }^{3}$, \\ M. Kousalya ${ }^{4}$ and Anbu N. Aravazhi ${ }^{5}$
}

Department of Microbiology, Karpagam Faculty of Medical Sciences and

Research, Coimbatore, India

*Corresponding author

\begin{abstract}
A B S T R A C T
Keywords

Uropathogenic

Escherichia coli, antimicrobial susceptibility, virulence factors, haemolysin, haemagglutination, serum resistance.

\section{Article Info}

Accepted:

20 August 2016 Available Online:

10 September 2016

Bacterial strains causing extra intestinal infections harbor virulence factors that enhance the ability to cause systemic infection. Uropathogenic Escherichia coli (UPEC) responsible for UTI express a multitude of virulence factors to break the inertia of the mucosal barrier. To study the haemolysin, haemagglutination and resistance to the bactericidal activity of the serum property as urovirulence factors of E.coli and antimicrobial susceptibility pattern. 100 E.coli strains isolated from urine samples out of 400 symptomatic cases were screened for virulence factors like Haemolysin, Mannose resistant, Mannose sensitive Haemagglutination (MRHA, MSHA) and Serum resistance by phenotypic methods. Antimicrobial susceptibility testing was done by Kirby-Bauer disc diffusion method as per CLSI guidelines. Among 100 E.coli strains 33\% were hemolytic, 9\% showed MRHA, $14 \%$ showed MSHA, there was no haemagglutination in $73 \%$ strains and $76 \%$ were serum resistant. Least percentage of resistance was seen to Imipenem (1\%), Piperacillin/tazobactum (1\%) and Nitrofurantoin (19\%). High percentage of resistance was found to Penicillins and Norfloxacin (79\%). The present study revealed that UPEC exhibited one or more virulence factors. Identifying virulence markers will definitely prevent the complications like recurrent, chronic and persistent urinary tract infections.
\end{abstract}

\section{Introduction}

Escherichia coli classified as the pathotype Uropathogenic Escherichia coli (UPEC) causing urinary tract infections usually occurs due to the movement of the strains from the intestinal tract or in some cases from the vagina into the urinary tract. It is considered as one of the most important opportunistic pathogen associated with UTI (Blanco et al., 1996) when the intestinal commensal turns to a pathogen moves out from its habitat, colonize host mucosal surfaces and circumvent host defenses to allow invasion of the normal sterile urinary tract (Mobley et al., 2000).

UPEC exhibits a wide variety of virulence properties, includes capsular $\mathrm{K}$ antigen, somatic $\mathrm{O}$ antigen, adherence, haemagglutination of erythrocytes, haemolysin, resistance to the bactericidal 
activity of serum, phagocytosis, cell surface hydrophobicity, expression of siderophore aerobactin, production of colicin $\mathrm{V}$ and cytotoxic necrotizing factor. These UPEC isolates express chromosomally encoded virulence markers and are expressed with different frequencies in different disease states ranging from asymptomatic bacteriuria to chronic pyelonephritis.

Adhesion is often mediated by fimbriae (pili) proteinacious, hairlike extensions from the bacterial cell surface that may recognise specific receptor structures like carbohydrates, on the epithelial cell membrane. These fimbriae have been studied mostly in $E$ coli in relation to gastroenteritis and UTI consisting of $\mathrm{P}$ fimbriae, type 1, afimbrial adhesins like $S$, Dr, afa.

Bacterial adhesion is divided into mannose sensitive (adhesion inhibited by mannose) type 1 fimbriae and mannose resistant (adhesion not inhibited by mannose) $\mathrm{P}$ fimbriae which helps the bacteria to resist the flow of urine by attaching to the uroepithelium and to the kidney cells with glycosphingolipids receptors.

\section{Haemolysin}

UPEC produces two types of haemolysin Beta haemolysin (cell bound) and Alpha haemolysin (cell free factor). Lysis of RBCs may result in makingiron and other nutrients available for the growth of bacteria contributing to tissue injury and survival in the renal parenchyma.

\section{P-Fimbriae}

Phenotypic expression of P-fimbriae can be detected by MRHA of human erythrocytes from individuals with the common blood group 'P', encoded by "papG”' gene (De Ree et al., 1987).

\section{Type-1 Fimbriae}

More important in bladder colonization than P-fimbriae, encoded by 'fimH'gene cluster. Phenotypic expression of Type-1 fimbriae can be detected by MSHA (Duguid et al., 1979).

\section{Serum Resistance}

Resistance to bactericidal activity of serum results from individual or combined effects of capsular polysaccharide, $\mathrm{O}$ antigen and surface proteins (Vijayalakshmi et al., 2015).

This study was undertaken to determine the prevalence of virulence factors haemolysin, serum resistance, haemagglutination of human erythrocyte and effect of D-mannose on haemagglutination in urinary isolates of $E$. coli obtained from a tertiary hospital.

\section{Materials and Methods}

The prospective study was conducted at the Department of Microbiology in a tertiary care hospital from October 2015 to March 2016. A total of 400 urine samples collected from the patients was labelled appropriately and transported immediately to the Microbiology laboratory for processing. The samples were cultured by bacteriological standards and confirmed as Escherichia coli by biochemical identification. The prevalence of virulence factors haemolysin, Haemagglutination, resistance to the bactericidal activity of serum. Antibiotic susceptibility pattern was carried out using Kirby-Bauer disc diffusion method.

\section{Antibiotic Susceptibility testing pattern}

Inoculum was prepared by inoculating the 2 to 3 colonies from culture media in nutrient broth and standardized with 0.5 MC Farland 
standard and swabbed onto a $90 \mathrm{~mm}$ MullerHinton agar plate using Kirby Bauer disc diffusion method and incubated at $37^{\circ} \mathrm{C}$ overnight and zone of inhibition was measured as per CLSI guidelines. Antibiotic

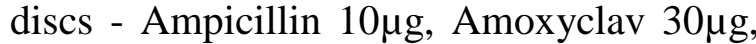
Cefuroxime $30 \mu \mathrm{g}$, Cefepime $30 \mu \mathrm{g}$,

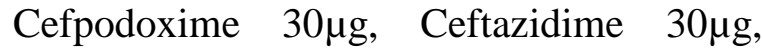
Ceftriaxone $30 \mu \mathrm{g}$, Gentamicin $10 \mu \mathrm{g}$, Norfloxacin $10 \mu \mathrm{g}$, Nitrofurantoin $300 \mu \mathrm{g}$, Nalidixic acid $30 \mu \mathrm{g}$, Co-trimoxazole $25 \mu \mathrm{g}$,

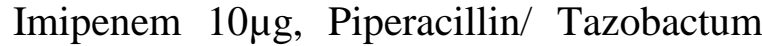
$100 / 10 \mu \mathrm{g}$ were used.

\section{Haemolysin production}

The plate hemolysis test was done for the detection of $\beta$-hemolysis produced by the $\mathrm{E}$. coli. The bacteria were inoculated into $5 \%$ sheep blood agar and incubated overnight at $35^{\circ} \mathrm{C}$. Hemolysin production was detected by the presence of a zone of complete lysis of the erythrocytes around the colony and clearing of the medium (Raksha et al., 2003).

\section{Haemagglutination of Human group $O$ erythrocytes}

The strains of E. coli was inoculated into $1 \%$ nutrient broth and incubated at $37^{\circ} \mathrm{C}$ for 48 $\mathrm{h}$ for full fimbriation. Blood group "O" red blood cells were then washed thrice in normal saline and made up to a 3\% suspension in fresh saline. They were used immediately or within a week when stored at $3-5^{\circ} \mathrm{C}$. The test was carried out on Venereal Disease Research Laboratory (VDRL) slides. One drop $(100 \mu l)$ of bacterial suspension was mixed with onedrop of erythrocytes and one drop of phosphate-buffered saline (PBS) with and without $3 \%$ mannose on a VDRL slide. The slide was rotated for five minutes at room temperature and the presence or absence of macroscopic haemagglutination was noted.
Haemagglutination was considered to be mannose resistant (MRHA) when it occurred in the presence of D-mannose indicating $\mathrm{P}$ fimbriae and mannose sensitive (MSHA), when it was inhibited by the presence of D-mannose representing type 1 fimbriae (Siegfried et al., 1994). Controls: For MSHA - ATCC 2922. For MRHA - In house control.

\section{Serum bactericidal activity}

Overnight cultures of E.coli grown at $37^{\circ} \mathrm{C}$ on Mueller Hinton agar (MHA) were harvested and the cells were suspended in Hank's balanced salt solution (HBSS). 50 $\mu 1$ each of bacterial suspension and serum were added to each well of microtitre plate. Control wells contained $50 \mu \mathrm{l}$ of HBSS only. $10 \mu 1$ of each sample and control was withdrawn and spread on MHA plate at $0 \mathrm{hr}$ and at $3 \mathrm{hrs}$ after incubation in water bath at $37^{\circ} \mathrm{C}$ for $3 \mathrm{hrs}$, incubated for $18-24 \mathrm{hrs}$ at $37^{\circ} \mathrm{C}$ and viable count was determined. Strains were termed serum sensitive if the viable count dropped to $1 \%$ of the initial value and resistant if $90 \%$ of organism survived after $3 \mathrm{hrs}$ incubation period.

\section{Results and Discussion}

Out of 400 urine samples 100 were E.coli isolates in which $66 \%$ were females and $34 \%$ of males. Maximum E.coli were isolated from the age group of $11-20$ yrs (19\%), $21-30$ yrs and 41 - 50 yrs each accounting $15 \%$, followed by $61-70 \mathrm{yrs}$ which is of $14 \%$ (Table 1 ).

Antibiotic susceptibility pattern showed $100 \%$ sensitivity to imipenem, piperacillin/tazobactum 99\%, followed by nirofurantoin $81 \%$, gentamicin $62 \%$, cotrimoxazole $59 \%$ and the resistance pattern was high in nalidixic acid 94\%, ampicillin $84 \%$, amoxyclav $84 \%$, norfloxacin $79 \%$, 
cefpodoxime $75 \%$, ceftriaxone $74 \%$, cefepime $73 \%$, cefuroxime $72 \%$, ceftazidime $71 \%$ (Table 2).

Among 100 E.coli isolates a) Haemolysin production: $33 \%$ had hemolytic property and $77 \%$ were non-hemolytic. b) Haemagglutination: $9 \%$ showed $\mathrm{P}$ fimbriae (MRHA), 14\% were Type 1 fimbriae (MSHA) and there is no haemagglutination in 73 isolates. c) Serum bactericidal activity: Higher resistance $76 \%$ to serum were noted in this study and the serum bactericidal action was present in only $24 \%$ isolates (Table 3).

Innature bacteria often stick to surfaces like stones, leaves, and roots. Epithelial cell surfaces make no exception. Bacteria belonging to the 'normal' flora as well as pathogens may adhere by hydrophobic or electrostatic bonds, or both, of an 'unspecific' nature, or through a specific interaction between bacterial adhesins and epithelial cell receptors (Gibbons et al., 1971; Savage et al., 1980; Colleen et al., 1982). The ability of pathogens to adhere to mucous membranes is recognized as a potential factor in virulence.

In this study, females were infected with high percentage of E.coli $66 \%$. This may be an expression of a more general biological abnormality, since buccal cells of women are prone to UTI showedan increased adhesive capacity (Duguid et al., 1955). In the present study, maximum percentage of isolates belonged to age group 11-20 years and 21-30 years in females. The inaccessibility of a qualified physician in the rural set up a woman of illiteracy, early marriages, poverty, ignorance and negligence of personal hygiene, all contribute to the development of UTIs in the sexually active age group in a developing country like ours, starts from a very early age after puberty (Rebecca et al., 2005).

\section{Urovirulence markers of E.coli isolates}

\section{Haemolysin}

In the present study, $33 \%$ of $\mathrm{E}$. coli isolates were positive for haemolysin. (Raksha et al., 2003) have reported $41.36 \%$ of strains to be haemolytic. (Mandal et al., 2001) reported $45.5 \%$ of strains to be haemolytic. In the study of (Rebecca et al., 2005), 40.7\% were hemolytic, (Vijyalakshmi et al., 2014) showed 25\% hemolytic.

\section{Haemagglutination}

MRHA of human RBCs is the phenotypic expression of P-fimbriae on E. coli. MSHA is the phenotypic expression of Type 1fimbriae which mediate adherence and are more important in bladder colonization than P- fimbriae.

\begin{tabular}{|l|l|l|l|}
\hline \multicolumn{5}{|c|}{ Percentage of Haemagglutination } \\
\hline Previous studies & $\begin{array}{l}\text { No. of } \\
\text { isolates }\end{array}$ & $\begin{array}{l}\text { \% MRHA } \\
\text { fimbriae) }\end{array}$ & $\begin{array}{l}\text { \% MSHA (Type 1 } \\
\text { fimbriae) }\end{array}$ \\
\hline Mandal et al., 2001 & 170 & 44 & 47 \\
\hline Rebecca et al., 2005 & 163 & 48 & 32 \\
\hline Manjula et al., 2006 & 160 & 40 & 34 \\
\hline N.Fatima et al., 2012 & 120 & 75 & 18 \\
\hline Vijyalakshmi et al., 2014 & 200 & 60 & 76 \\
\hline
\end{tabular}




\begin{tabular}{|l|c|c|c|}
\hline \multicolumn{3}{|c|}{ Percentage of Serum bactericidal assay } \\
\hline Previous studies & No. of isolates & $\begin{array}{c}\text { \% Serum } \\
\text { Resistant }\end{array}$ & $\begin{array}{c}\text { \% Serum } \\
\text { Sensitive }\end{array}$ \\
\hline Prabhat et al., 2010 & 220 & 32.72 & 67.28 \\
\hline Vijayalakshmi et al., 2014 & 200 & 49 & 51 \\
\hline Yasmeen Kausar et al., 2009 & 200 & 49.5 & 51.5 \\
\hline Present study & 100 & 76 & 24 \\
\hline
\end{tabular}

The present study showed 9\% P fimbriae (MRHA), 14\% were Type 1 fimbriae (MSHA) and there was no haemagglutination in $73 \%$ isolates and showed very less percentage of MRHA and MSHA type of haemagglutination when compared to the previous studies. The reason behind it may be that, the phenotype expression was absent in vivo, masked by some mutation, can also vary depending upon host characters, type of infection and predisposing factors determining the host parasite interaction in vivo which can culminate in an active infection and this may or may not recur (Johnson et al., 1991; Shrikhande et al., 1999).

Measuring a phenotype in vitro does not always correlate with in vivo expression and very often underestimates the presence of a virulence factor in vivo (Kaper et al., 2004). Also identifying a genotype does not mean that it is always expressed in the body. The in vitro study of the phenotypic characters of uropathogenicity is only a presumption of a possible recurrent UTI.

Table.1 Age and Gender distribution of E.coli isolates among symptomatic UTI patients

\begin{tabular}{|l|c|c|c|}
\hline \multirow{2}{*}{ Age } & \multicolumn{2}{|c|}{ No. of E.coli } & \multirow{2}{*}{ Total } \\
\cline { 2 - 3 } & Male & Female & \\
\hline$\leq 1-10$ & 1 & 9 & $\mathbf{1 0}$ \\
\hline $\mathbf{1 1 - 2 0}$ & $\boldsymbol{8}$ & $\mathbf{1 1}$ & $\mathbf{1 9}$ \\
\hline $21-30$ & 5 & 10 & $\mathbf{1 5}$ \\
\hline $31-40$ & 1 & 6 & $\mathbf{7}$ \\
\hline $41-50$ & 4 & 9 & $\mathbf{1 3}$ \\
\hline $51-60$ & 5 & 10 & $\mathbf{1 5}$ \\
\hline $61-70$ & 6 & 8 & $\mathbf{1 4}$ \\
\hline $71-80$ & 3 & 3 & $\mathbf{6}$ \\
\hline $81-90$ & 1 & 0 & $\mathbf{1}$ \\
\hline $91-100$ & 0 & 0 & $\mathbf{0}$ \\
\hline Total & 34 & 66 & $\mathbf{1 0 0}$ \\
\hline
\end{tabular}


Table.2 Antibiotic Susceptibility pattern of E.coli from urine samples.

\begin{tabular}{|l|c|c|}
\hline Antibiotics & Sensitive \% & Resistant \% \\
\hline Ampicillin & 16 & 84 \\
\hline Amoxyclav & 16 & 84 \\
\hline Ceftriaxone & 26 & 74 \\
\hline Cefuroxime & 28 & 72 \\
\hline Norfloxacin & 21 & 79 \\
\hline Nalidixic acid & 6 & 94 \\
\hline Nitrofurantoin & 81 & 19 \\
\hline Cefepime & 27 & 73 \\
\hline Cefpodoxime & 25 & 75 \\
\hline Ceftazidime & 29 & 71 \\
\hline Gentamicin & 62 & 38 \\
\hline Co-trimoxazole & 59 & 41 \\
\hline Imipenem & 100 & 0 \\
\hline Piperacillin/Tazobactum & 99 & 1 \\
\hline
\end{tabular}

Table.3 Virulence markers of UPEC

\begin{tabular}{|c|c|c|}
\hline S.No. & Virulence markers & Percentage \\
\hline 1. & $\begin{array}{c}\text { Haemolysin production } \\
\text { - Hemolytic } \\
\text { - Non-hemolytic }\end{array}$ & $\begin{array}{l}33 \% \\
77 \%\end{array}$ \\
\hline 2. & $\begin{array}{cc}\text { Haemagglutination } \\
\bullet & \text { MRHA } \\
\bullet & \text { MSHA } \\
\bullet & \text { NO HA }\end{array}$ & $\begin{array}{l}9 \% \\
14 \% \\
73 \%\end{array}$ \\
\hline 3. & $\begin{array}{c}\text { Serum bactericidal assay } \\
\text { - } \quad \text { Serum resistance } \\
\text { - Serum sensitive }\end{array}$ & $\begin{array}{l}76 \% \\
24 \% \\
\end{array}$ \\
\hline
\end{tabular}

Fig.1 $\beta$-hemolysin production

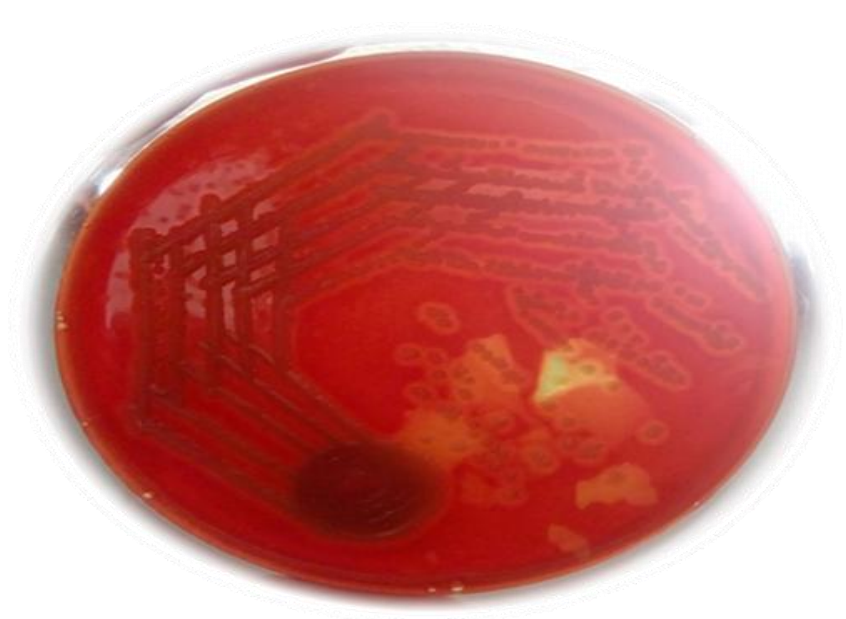


Fig.2a Haemagglutination - Macroscopic appearance
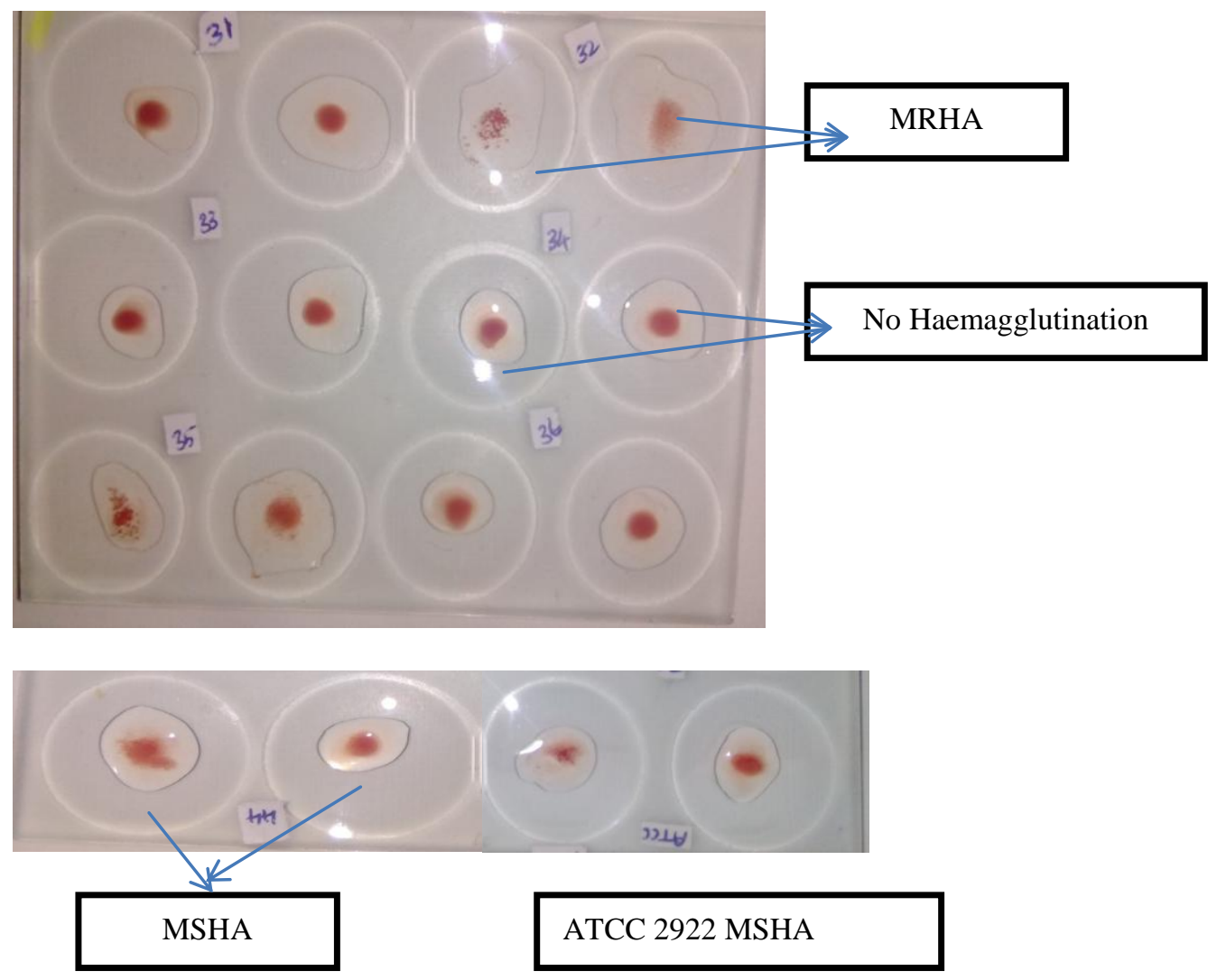

Fig.2b Haemagglutination - Microscopic appearance under low power (10x) objective.

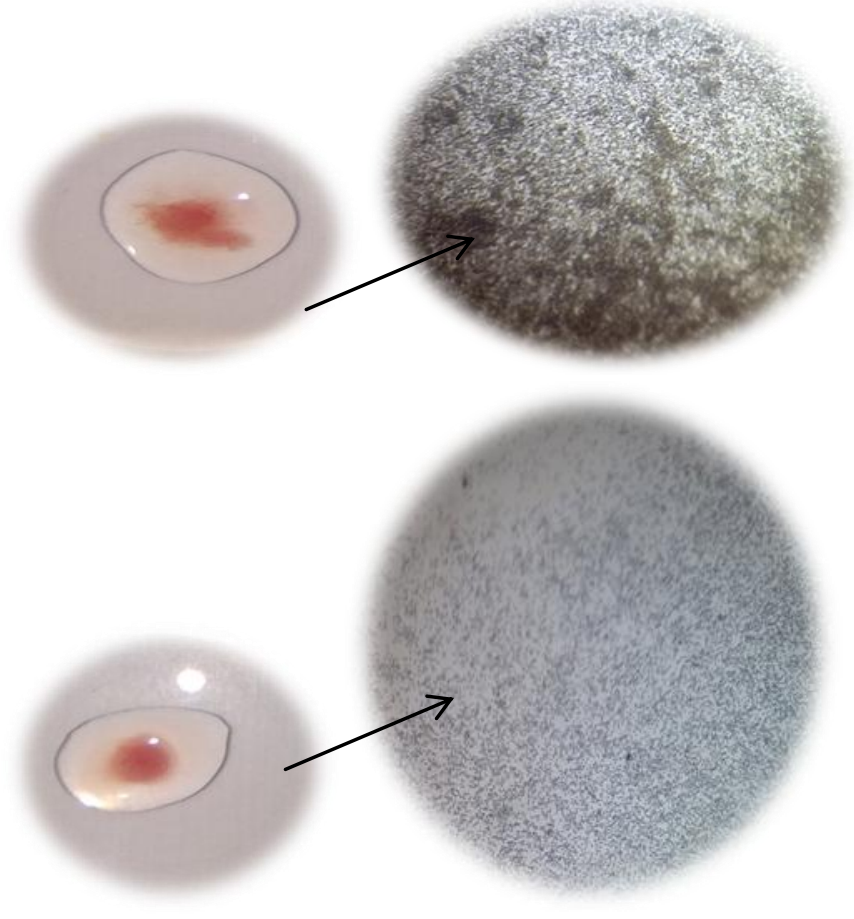

Clumping of RBCs by fimbriae - Presence of haemagglutination

No clumping of RBCs by fimbriae Absence of haemagglutination 
Fig.3 Serum bactericidal activity

$0 \mathrm{hr}$
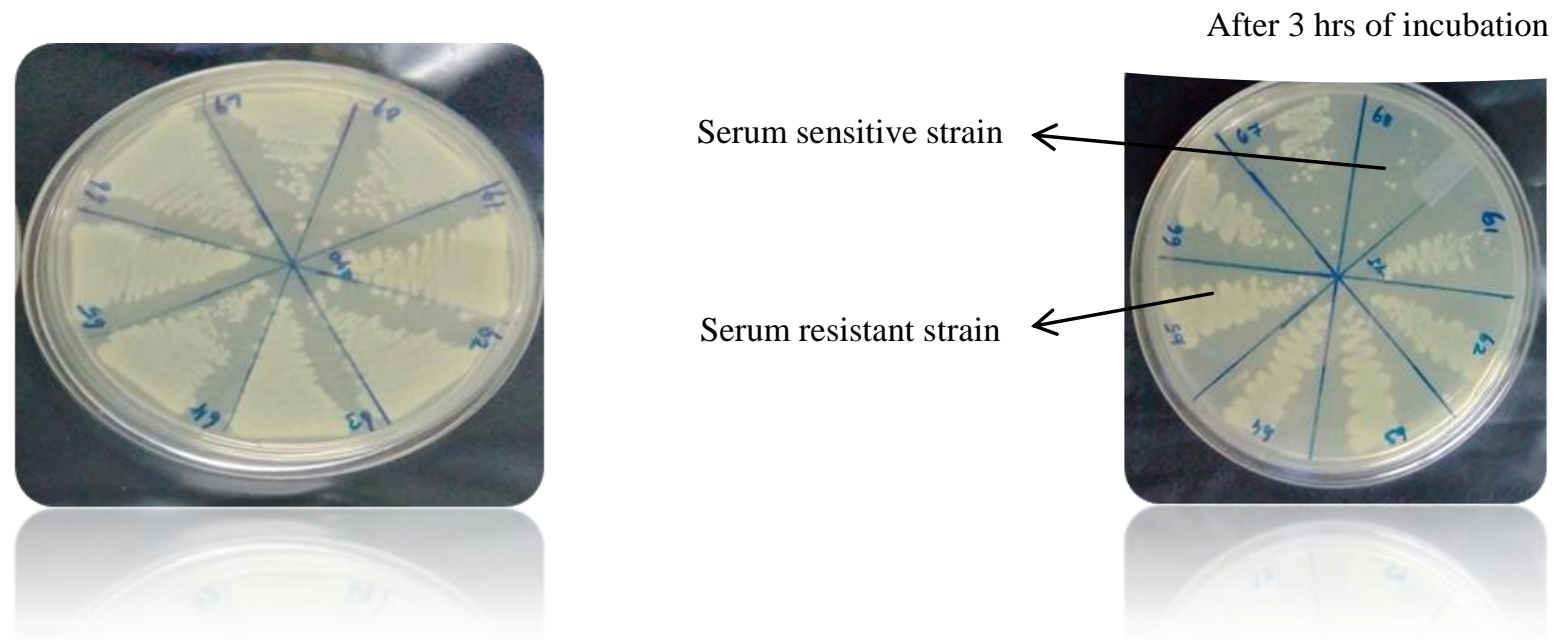

\section{Serum Bactericidal activity}

The capsule/K antigen on the cell surface may confer serum and phagocyte resistance to some E.coli strains (Warren et al., 1999).Comparing to other studies, this study showed that a higher percentage of resistance towards serum. This property was attributed to the content of sialic acid, which reduced the ability of the bacterial surface to activate and complement by an alternative pathway (Altwegg et al., 1998).

In the present study, Imipenem, Piperacillin/ tazobatum, Nitrofurantoin, are observed to be the antibiotics of choice. Empirical antimicrobial treatment is initiated alin almost all UTIs before the laboratory results of the urine culture are available (Dash et al., 2013). Misuse and self-medication in many countries, including India may be considered a major problem as antibiotics could be purchased without any prescription. Up to $95 \%$ of UTI cases are treated without bacteriological investigations (Warren et al., 1999). Many reports suggested that the resistance of E.coli strains to commonly used antimicrobial agents have been rising rapidly.
In conclusion, there is a need to define the strategies better to prevent the emergence and more studies in this area are clearly required. Periodic review and formulation of antiobiotic policy are needed for control of acquisition of drug resistance. Further studies on better understanding of the interaction of different virulence factors at the molecular level are necessary as most urovirulent strain expresses multiple virulence factors simultaneously.

\section{References}

Altwegg, Bockemuhl, J. 1998. Escherichia and Shigella. In: Collier L, Balows A, editors. Topley and Wilsons Microbiology and Microbial infections. Systematic bacteriology. 9th ed. London: Edward Arnold, 9403.

Blanco, M.J.E., Blanco, M., Alonso, P., and Blanco, J. 1996. Virulence factors and $\mathrm{O}$ groups of Escherichia coli isolates from patients with acute pyelonephritis, cystitis and asymptomatic bacteriuria. Eur. J. Epidemiol., 12(2): 191-198. 
Colleen, S.L.Y. 1982. The human urethral mucosa. An experimental study with emphasis on microbial attachment. Scand J. Urol. Nephrol., 68.

Dash, M., Padhi, S., Mohanty, I., Panda, P., and Parida, B. 2013. Antimicrobial resistance in pathogens causing urinary tract infections in a rural community of Odisha, India, J. Family Community Med., 20(1): 20-26.

De Ree, J.M., Van den Bosch, J.F. 1987. Serological response to the $\mathrm{P}$ fimbriae of uropathogenic E.coli in pyelonephritis. Infect. Immun., 55(9): 2204-7.

Duguid, J.P., Cleggs, Wilson, M.I. 1979. The fimbrial and non fimbrial haemagglutinins of E.coli. J. Med. Microbiol., 12: 213-27.

Duguid, J.P., Smith, I.W., Dempster, G., Edmunds, P.N. 1955. Non- flagellar filamentous appendages ("fimbriae") and haemaggluti- nating activity in Bacterium coli. J. Pathol., 70: 335-48.

Fatima, N., Mithesh Agrawal. Characterization of Uropathogenic E. coli in relation to virulence Factors. Open Access Scientific reports.

Gibbons, R.J., Houte, J. van. 1971. Selective bacterial adherence to oral epithelial surfaces and its role as an ecological determinant. Infect. Immun., 3: 56773.

Johnson, J.R. 1991. Virulence factors in E. Coli UTI. Clin. Microbiol. Rev., 4(1): 80-128.

Mobley, H.L. 2000. Virulence of the two primary uropathogens. ASM News, 66: 403-10.

Prabhat Ranjan, K., Neelima Ranjan, Arindam Chakraborty, D.R. Arora. 2010. An Approach to Uropathogenic Escherichia coli in Urinary Tract Infections. J. Lab. Physicians, 2(270): 70-74.
Raksha, R., Shrinivasa, H., Mawcaden, R.S. 2003. Occurrence and characterization of uropathogenic Escherichia coli in urinary tract infection. Ind. J. Med. Microbiol., 21: 102-107.

Rebecca Naveen, Elizabeth Mathai. 2005. Some Virulence Characteristics of Uropathogenic E. coli in different patient groups. Ind. J. Med. Res., 143147.

Savage, D.C. 1980. Adherence of normal flora to mucosal surfaces. In: Beachey $\mathrm{EH}$, ed. Bacterial adherence. (Receptors and recognition, series $\mathrm{B}$, vol 6.) London and New York: Chapman and Hall, 30-59.

Shrikhande, S.N., Chande, C.A., Pathak, A. 1999. Virulence factors in uropathogenic E.coli. Ind. J. Path. Microbiol., 42: 321-25.

Siegfried, L., Kmetová, M., Puzová, H., Molokácová, M., Filka, J. 1994. Virulence associated factors in Escherichia coli strains isolated from children with urinary tract infections. J. Med. Microbiol., 41: 127-132.

Siegfried, L., Kmetová, M., Puzová, H., Molokácová, M., Filka, J. 1994. Virulence associated factors in Escherichia coli strains isolated from children with urinary tract infections. J. Med. Microbiol., 41: 127-132.

Vijayalakshmi, J., R. Hymavathi, A. Renuka Devi, M.V. Ramanamma. G. Swarnalatha, A. Surekha, V. Anitha Lavanya, R. Somasekhar. 2015. "Study of Virulence Factors in Uropathogenic Escherichia Coli". $J$. Evol. Med. Dent. Sci., 4(8): 12971305.

Virulence factors in uropathogenic E.coli. Ind. J. Path. Microbiol., 42: 321-25.

Warren, J.W. 1997. Host parasite interactions and host defence mechanisms. In: Schrier RW, Gottschalk CW, editors. Diseases of 
the kidney. 6th ed. London: Little Brown, 873-94.

Warren, J.W. 1997. Host parasite interactions and host defence mechanisms. In: Schrier RW, Gottschalk CW, editors. Diseases of the kidney. 6th ed. London: Little Brown, p. 873-94.

Warren, J.W., Abrutyn, E., Hebel, J.R., James, R.J., Anthony, J.S., and Stamm, W.E. 1999. Guidelines for Antimicrobial Treatment of Uncomplicated Acute Bacterial Cystitis and Acute Pyelonephritis in Women, Clin. Infect. Dis., 29: 745-58.
Warren, J.W., Abrutyn, E., Hebel, J.R., James, R.J., Anthony, J.S., and Stamm, W.E. 1999. Guidelines for Antimicrobial Treatment of Uncomplicated Acute Bacterial Cystitis and Acute Pyelonephritis in Women, Clin. Infect. Dis., 29: 745-58.

Yasmeen Kausar, Sneha, K., Chunchanur, Shobha, D., Nadagir, L.H. Halesh and M.R. Chandrasekhar. 2009. Virulence factors, Serotypes and Antimicrobial Susceptibility Pattern of Escherichia coli in Urinary Tract Infections. Al Ameen J. Med. Sci., 2(1): 47-51.

\section{How to cite this article:}

Nachammai, S.M., Karthika Jayakumar, Vinithra Suresh, M. Kousalya and Anbu N. Aravazhi. 2016. Haemagglutination and Resistance to the Bactericidal Activity of Serum as the Urovirulence Markers of Uropathogenic Escherichia coli. Int.J.Curr.Microbiol.App.Sci. 5(9): 514-523. doi: http://dx.doi.org/10.20546/ijcmas.2016.509.057 